\title{
The lost value of street trees in the context of possible replacement and compensatory planting based on the case of selected streets in Warsaw
}

\author{
Marzena Suchocka $^{1 *}$, Agnieszka Kosiba ${ }^{2}$, Agata Milanowska ${ }^{1}$ \\ ${ }^{1}$ Warsaw University of Life Sciences, Nowoursynowska 166 St, 02-787 Warsaw, Poland \\ "e-mail: marzena.suchocka@interia.pl \\ ${ }^{2}$ Institute of Spatial Management and Housing, Targowa 45 St, 03-728 Warsaw, Poland
}

Received: 4 January 2018 / Accepted: 5 May 2018

\begin{abstract}
Street trees grow in extreme habitat conditions and are exposed to high anthropogenic pressure. This study presents changes that occurred in the resources of street trees in the selected part of Praga-North, a district located near the center of Warsaw, between 2011 and 2016. During this period, the number of dead and removed trees was determined and the assessment of the lost value was conducted. The compensatory value was evaluated as well. The replacement value was estimated in the examined area based on the difference between the value of the removed and newly-planted trees.

The study also shows the real number of conducted compensatory planting for the environmental loss. The research was conducted with the objective to determine the changes in the urban forest in the selected, highly-urbanized part of Warsaw. The study evaluated the extent of losses between the removed and newly-planted trees that allowed to assess the range of substitutes needed to be planted.
\end{abstract}

Key words: planting substitutes, compensatory value, tree, the value of trees, tree removal.

\section{Introduction}

The city is a structure, in which the technical infrastructure (buildings, structures, circulation area, aboveground and underground industrial networks) called „the grey infrastructure" mixes the surface and the green area, i.e. ,the green infrastructure".

Goods made by people have their market value and represent the fixed assets of the cities. Trees are considered as the non-market goods, which do not participate in the trade turnover. For that reason, ,the green infrastructure", including trees, is assumed to be undervalued. However, more often urban trees are considered by economists to be «fixed assets», interspersed throughout our cities, but which have no specific price in a perfectly competitive market (Simpferdorfer, 1979; Fabbri, 1989; Caballer, 1989, 1999).
Urban forest is under protection in most European cities (Schmied \& Pillman, 2003) but the development of the urban agglomeration results in the changes of the site conditions for plants. Urban changes have an impact on the decrease of the green areas (Szczepanowska, 2015). The trees growing in the pavement crossing along the streets are especially exposed to extreme habitat conditions. The limited soil volume for the roots, space for tree crowns and the anthropogenic pressure (air pollution, bad conditions considering air and water caused by the soil density, salinization, mechanical damages) results in the premature dying of trees (Ziemiańska \& Suchocka, 2013; Hauer et al., 1994; Miller \& Neely, 1993; Morell, 1992). New plants are being planted, yet most frequently not in the number that would compensate for the lost value (Pauleit et al., 2002; Suchocka \& Krynicki, 2016). 
In the place of the removed trees the new ones are being planted but the benefits of young plant material can't be compared to ecosystem services of mature tree. In Poland, the general rule of obtaining permission to remove trees and bearing administrative cost for its' removal remains in force. Nevertheless, there are many exceptions to this rule. The legal regulations in the field of incurred expenses and punishments for the removal without permit are restricted by the nature conservation act (Ustawa, 2001). The administrative authority is entitled, instead of administrative fee, to impose an obligation of replacement planting. In Poland regulations concerning replacement planting, that is implemented in the exchange of the removed one, are too generic. According to the nature conservation act the amount of the substitutes cannot be smaller than the number of the removed trees and shrubs. It can be even bigger, however, even after the amendment to the act from 28th September 2015 (Ustawa, 2015), it was not precisely indicated how the number of the tree substitutes is defined by the authority, what may lead to numerous problems related to the determination of the measurement of new planted substitute. Local authorities and society should be mindful of the fact that the natural value of the mature tree is incomparable with the value of the new planted tree from the nursery. The compensation for the lost common welfare and natural good is difficult or impossible to achieve in a short period of time. Everyone should be aware of the fact that after the removal of the tree, for example 60 -year-old tree, we have to wait for the similar effect at least over the next 50 years.

The fact that trees in cities should be estimated differently than the wood in the forest has already been noted for over one hundred years. Stone (2000) at the University of Michigan introduced for the first time the method of urban tree valuation, but still with a high degree of arbitrariness (Currid ed., 2000). Then in 1930 Felt and Spicer developed a more complex tree valuation method, based on values obtained on the basis of measurement data and supplementary factors. One of the subsequent methods of the currently binding urban tree valuation is benefit-based tree valuation (McPherson, 2007). Another approach is the replacement value, which is the value that society loses in the outcome of tree dying or cutting (Szczepanowska \& Latos, 2009). The replacement value, which is also called the structural or compensatory value, determines the real cost that should be defrayed so as to recreate the lost value of the tree resources (Helliwell, 2000). Based on replacement value Nowak et al. (2002) counted the value of the tree as an asset. The total compensatory value for the urban forests of the 48 adjacent United States is estimated at $\$ 2.4$ trillion. That kind of data is an argument for decision makers that enables them a better foundation and comprehension for urban tree management. Currently in Poland there are any legally effective methods enabling calculation of the non-market estimated value of the existing tree or the ones that are being removed in the city. Institute of Spatial Management and Housing (IGPiM) along with Warsaw University of Life Sciences (SGGW) developed the method of the tree valuation in 2009 and the one modified in 2015 for the Ministry of the Environment (Szczepanowska et al., 2010). This method makes possible to determine the compensatory tree value and is called the replacement valuation method.

The mentioned above method of the tree valuation, based on the cost of the replacement (the IGPiM method), allows to determine the compensation based on sizes of the trees that are subject to be removed. One example of such practices could be the procedures established on the area of New York (Szczepanowska \& Latos, 2008). The way of figuring the compensation for the lost trees evolved together with the increase of the social awareness of the meaning of trees for the environment. Originally, when someone was compensating for the losses for the lost tree, it was enough to plant one tree of the size available in the forest nursery, not taking into account the size of the removed tree. In the next stage, it was acknowledged that compensation should compose the number of the trees, which sum of the diameters of the tree trunks ought to be equal with the removed one. Only in the 90s the rule was introduced and on the basis of it „the basic value" of the sectional area measuring the diameter at breast height was settled. The needed amount of the saplings is determined as a sum of the sectional areas compensates the lost tree. For example, if the mature red oak with the diameter of the tree trunk of $30 \mathrm{~cm}$ has the volume of the trunk of about $706 \mathrm{~cm}^{2}, 16$ trees with the sectional area of $44 \mathrm{~cm}^{2}$ or 9 trees with the sectional area of $78 \mathrm{~cm}^{2}$ need to be planted in order to compensate for the loss. Local government in Cracow has introduced a good practice of the local department of environment protection considering planting substitutes. There was determined that substitutes would be planted in such amount that the sum of the diameters of the tree trunks would be equal with the removed ones. In a row in Germany in the situation of the lack of space for planting substitutes on the plot, where the trees are being removed, the money for the cut tree is deposited in the tree bank and dedicated to the maintenance of the trees that has been planted or to improve habitat conditions of the trees that are going to be planted. It also includes the financial means for designing and carrying out project solutions that enable the development of, for example, impervious surface, suspended pavement or structural soil.

Municipal arborists are frequently faced with choices regarding which species to plant, where and whether to retain existing trees or remove and replace them. (McPherson, 2007). In Polish conditions, the lack of financial valuation of the urban forest is an important problem that results in poor selection of planting material parameters. Additional problem is poor care - a small size of planted 
trees that are not properly maintained, increases the need to implement valuation methods. There are any specific standards in Poland. Often the smallest nursery material is planted, which cannot cope with difficult site conditions. In Germany and Sweden, young trees with trunk circumferences of 16-18 minimum are used for replacement plantings, as in the standard for Warsaw (Borowski \& Pstrągowska, 2009) or bigger like $18-20 \mathrm{~cm}$, in one third of cities in Western Europe even 20-25 cm (Pauleit et al., 2002). In Brussels, even larger trees are planted, with tree trunks circumferences over $30 \mathrm{~cm}$. These questions might have been answered using the benefit-based approach.

The first aim of the work was to assess the possibility of conducting urban forest management based on an economic tool to determinate environmental compensation for green areas in cities. The second aim of the work is to determine the suitability of the method for Polish conditions on the example of a fragment of one of the main districts of the Polish capital.

We hypothesized that the introduction of the tree valuation method based on the replacement cost is necessary in Poland in order to assess the losses and benefits of tree planting and, in the case of losses, potentially could be a supplementation of the guidelines in the environment protection act. Therefore, the mandatory requirement of planting the bigger number of trees for the one that is being removed is justified, but implementation of the tools that make it possible to evaluate the losses and determine the adequate compensation for its renewal is required. The analysis of the excessive tree removal problem and connected with it loss of tree asset of the city has been carried out in this article.

\section{Methods}

In the examined period of 5 years between 2011 and 2016 the analysis of the inventory and the verification of the conditions of the tree stands on their basis was assigned. In the paper the inventory of the street trees within the streets: Solidarności, Targowa, Zielenieckiej, Zamojskiego and Jagiellońska (Fig. 1) was conducted. This field of Praga North (Polish: Praga-Pótnoc), which represents the district of Warsaw, is highly-urbanized. The inventory was carried out in February in 2016. During the process, the tree species and trunk circumference on the height of 130 centimeters were considered. Additionally, the trees were described in terms of the condition and location. As previously mentioned, a similar inventory was conducted in 2011 and thereby an opportunity to compare the changes

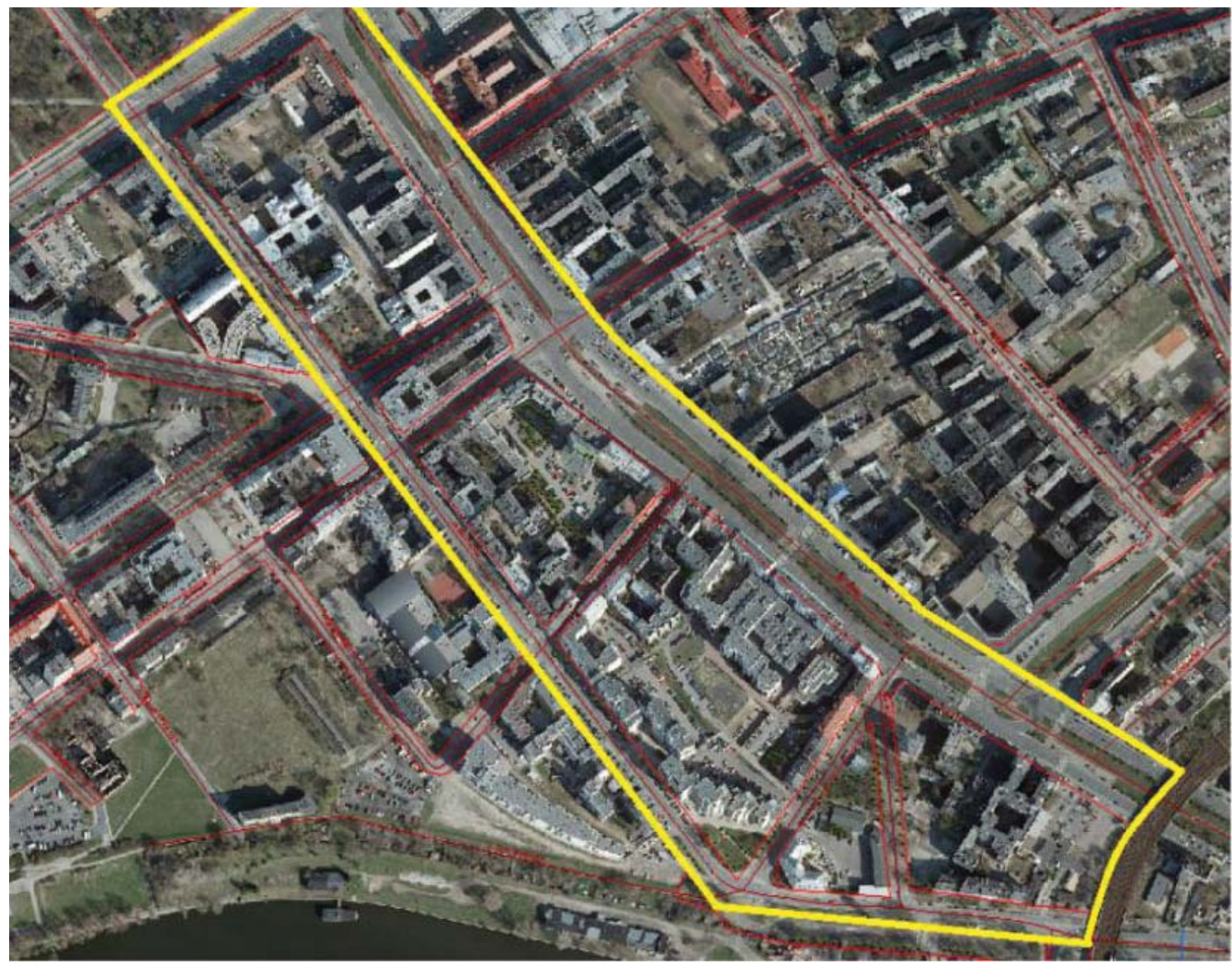

Figure 1. The area of monitoring and conducting the analysis and research (marked by the yellow line) 
in the coppices in the period of 5 years has occurred. The method of value valuation based on IGPiM replacement costs was chosen as the most suitable, easy to apply and explain to local community, which gives the greatest opportunities for field application. This method considers such essential elements as the basic coefficient, the species, the location and the condition coefficients (Szczepanowska et al., 2010).

To achieve the assumed target were determined the number, species and conditions of the trees which were cut and newly-planted on the examined field from 2011 to 2016. As mentioned above the basis to conduct the research was the tree inventory from 2011. The update of the tree inventory has made it possible to calculate the lost replacement value (the compensatory value) between the removed and newly-planted trees.

With the object of counting the number of the compensatory trees for the environmental damages the following formula was used: $\mathbf{C P}=\mathrm{L} / \mathrm{BR}$.

Compensation planting (CP) - the amount of the trees that would compensate for the environmental damages.

Losses $(\mathbf{L})=$ the replacement value of the removed trees - the replacement value of the substitutes (the new trees).

The valuation of trees in a group of $\mathrm{CP}$ and $\mathrm{L}$ was made based on a method developed by the IGPiM/SGGW team of authors under the supervision of prof. H. B. Szczepanowska in 2009 (Borowski \& Pstrągowska, 2009; Kosmala et al., 2009; Szczepanowska \& Latos, 2009; Szczepanowska et al., 2009). The basis for the valuation of the trees in the method were the replacement cost of the tree. The method assumes that trees, which can be reproduced in the form of natural restitution, are located in the range of $20-25 \mathrm{~cm}$ of the trunk perimeter. It was assumed that the cost of a growing tree with a trunk circumference of $20 / 25 \mathrm{~cm}$ is the so-called base rate (BR), which is the basis for calculating the monetary value (BV) of trees with larger or smaller trunk circumferences. The other parameters of the tree valuation are: tree measurement at the height of $1.3 \mathrm{~m}$, coefficients of the species value $(\mathrm{G})$ and tree increment factors $(\mathrm{P})$. The actual tree value (ATV) is the product of the tree's basic value (BV) and the coefficients of condition $(\mathrm{K})$ and location $(\mathrm{L})$ :

$$
\mathrm{ATV}=\mathrm{BV} \times \mathrm{K} \times \mathrm{L}
$$

BR - the base rate from the method IGPiM/SGGW used for calculations was verified for the 2016. The base rate was increased by current inflation rate.

The differences in the number and "quality" between the tree stands from 2011 to 2016 were examined. The results of the research and analysis in the field of inventory, decline in the tree stands and compensatory planting were formulated below.

\section{Results}

Inventory that was conducted in 2016 concerns 287 trees (Table 1). The number of the removed, replaced and newly-

Table 1. The comparison of the tree stands between 2011 and 2016 in the chosen area of Praga North

\begin{tabular}{|l|c|c|c|c|c|}
\hline \multicolumn{1}{|c|}{ Street name } & $\begin{array}{c}\text { The overall } \\
\text { number of trees } \\
\text { in 2011 }\end{array}$ & Removed trees & Replaced trees & $\begin{array}{c}\text { Newly-planted } \\
\text { trees }\end{array}$ & $\begin{array}{c}\text { The overall } \\
\text { number of trees } \\
\text { in 2016 }\end{array}$ \\
\hline Zamoyskiego & 40 & 8 & 0 & 9 & 41 \\
\hline Solidarności & 9 & 4 & 0 & 0 & 5 \\
\hline Jagiellońska & 74 & 4 & 4 & 9 & 83 \\
\hline Marcinkowskiego & 14 & 6 & 7 & 0 & 14 \\
\hline Kłopotowskiego & 15 & 7 & 7 & 0 & 15 \\
\hline Targowa & 121 & 32 & 2 & 0 & 103 \\
\hline Sprzeczna & 18 & 3 & 0 & 0 & 9 \\
\hline Kępna & 9 & 0 & 0 & 26 & 0 \\
\hline Okrzei & 300 & 64 & & & 287 \\
\hline The total amount & & & & & 0 \\
\hline
\end{tabular}


planted trees was analyzed. The replacement planting means trees planted in the same place where the trees were cut. Whereas, new planting relates to creating a new place that has not existed until now.

\subsection{Analysis of the tree decline between 2011 and 2016 and the extent of the replacement planting}

The calculation of the value of the removed trees on the streets in the research area of Praga North were done following the method of the Institute of Spatial Planning and Housing (Table 2).

For each of the removed tree the replacement value for 2016 was calculated. The value was determined for the existing, removed or replaced and newly-planted trees.

The aggregated value of the removed trees on every street in 2016 was also calculated. The lost trees on the Targowa Street had the biggest value of 364,313.31 zlotys. A big decline of trees in this period was caused by hard site conditions, but also partially by building the second line of the metro in Warsaw. The replacement value (the compensatory value) of the lost trees on streets is $58.74 \%$
Table 2. The profile of the replacement value by the method IGPiM according to the streets

\begin{tabular}{|l|c|}
\hline \multicolumn{1}{|c|}{ Street name } & $\begin{array}{c}\text { The replacement value } \\
\text { of the removed trees (in zlotys) }\end{array}$ \\
\hline Zamoyskiego & $85,297.91$ \\
\hline Solidarności & $45,533.64$ \\
\hline Jagiellońska & $27,385.46$ \\
\hline Marcinkowskiego & $56,384.79$ \\
\hline Kłopotowskiego & $37,341.98$ \\
\hline Targowa & $364,313.31$ \\
\hline Sprzeczna & $3,977.51$ \\
\hline Kępna & - \\
\hline Okrzei & - \\
\hline Total value & $620,234.60$ \\
\hline
\end{tabular}

Table 3. The profile of the replacement value of the removed trees and number of the cut trees by species between 2011 and 2016

\begin{tabular}{|c|c|c|}
\hline Tree species & The replacement value by species (in zlotys) & $\begin{array}{c}\text { The number } \\
\text { of the removed } \\
\text { trees }\end{array}$ \\
\hline Quercus robur & $229,563.68$ & 9 \\
\hline Tilia cordata & $84,241.77$ & 6 \\
\hline Acer pseudoplatanus & $61,043.29$ & 11 \\
\hline Acer saccharinum & $48,813.55$ & 7 \\
\hline Ulmus laevis & $49,061.94$ & 4 \\
\hline Acer platanoides & $37,267.93$ & 5 \\
\hline Fraxinus excelsior & $29,526.30$ & 2 \\
\hline Pyrus calleryana 'Chanticleer' & $17,796.56$ & 7 \\
\hline Quercus rubra & $14,261.76$ & 1 \\
\hline Tilia platyphyllos & $14,856.00$ & 2 \\
\hline Tilia euchlora & $11,092.48$ & 1 \\
\hline Acer pseudoplatanus & $6,759.48$ & 1 \\
\hline Platanus acerifolia & $4,993.56$ & 4 \\
\hline Acer ginnala & $3,367.36$ & 1 \\
\hline Robinia pseudoacacia ,Bessoniana' & $3,156.90$ & 1 \\
\hline Styphnolobium japonicum & $2,575.04$ & 1 \\
\hline Robinia pseudoaccacia 'Umbraculifera' & $1,857.00$ & 1 \\
\hline
\end{tabular}


in proportion to the total amount of the replacement value of the trees on the researched area (Table 2).

The Table 3 presents the relation between the number of the removed trees and the replacement value. The biggest structural loss concerns the common oak. The lost value equals 229,563.68 zlotys from 9 removed trees. The average value of the common oak was estimated at 25,507.08 zlotys. Whereas, the biggest number of the removed trees is 11 of Acer negundo. Their replacement value is 61,043.29 zlotys and the estimated value of one Acer negundo is 5,549.39 zlotys. Such an enormous difference in the values comes from the fact that oaks were the trees of several decades, big sizes and in good condition.

The biggest amount of the newly-planted trees comes from Platanus sp. and Pyrus calleryana. The total amount of them constitutes 19 trees which is $37.25 \%$ in proportion to all of the newly-planted trees. They are the species of the foreign origin. Pyrus calleryana do not match proportionally the wide streets (for example Targowa Street) because of its' style.

On the researched area within the period of 5 years $(\mathrm{Ta}-$ ble 1) 64 trees were removed which is $21.33 \%$ of the total amount. The number of the replaced and newly-planted trees is 51 . With the aim of planting replacements according to the rule one to one 13 more trees are needed which is a loss of $20.31 \%$.Regarding the nature conservation act from 16th April 2004 the replacement planting (planting of new trees) should be done at least accordingly to the rule one to one (for one removed tree, the one new has to be planted). On the selected field the appropriate
Table 4. The profiles of the replacement value of the newly-planted and replaced trees between 2011 and 2016 on the chosen area of Praga North

\begin{tabular}{|l|c|c|}
\hline \multicolumn{1}{|c|}{ Tree species } & $\begin{array}{c}\text { The number } \\
\text { of newly- } \\
\text { planted } \\
\text { trees }\end{array}$ & $\begin{array}{c}\text { The replacement } \\
\text { value (in zlotys) }\end{array}$ \\
\hline Acer platanoides & 9 & $17,084.40$ \\
\hline Platanus acerifolia & 15 & $20,922.75$ \\
\hline Robinia pseudoacacia & 11 & $20,427.00$ \\
\hline Pyrus calleryana & 14 & $38,967.30$ \\
\hline Tilia sp. & 1 & $1,857.00$ \\
\hline Fraxinus excelsior & 1 & $1,857.00$ \\
\hline Total value & 51 & $101,115.45$ \\
\hline
\end{tabular}

amount of the trees to fulfil the basic requirements of the nature conservation act was not planted. The number of the removed trees on the researched area was 64 and only 51 were planted (Table 4). To comply with the basic replacement planting 14 more trees are needed. It is a loss of $20.31 \%$ (Fig. 2).

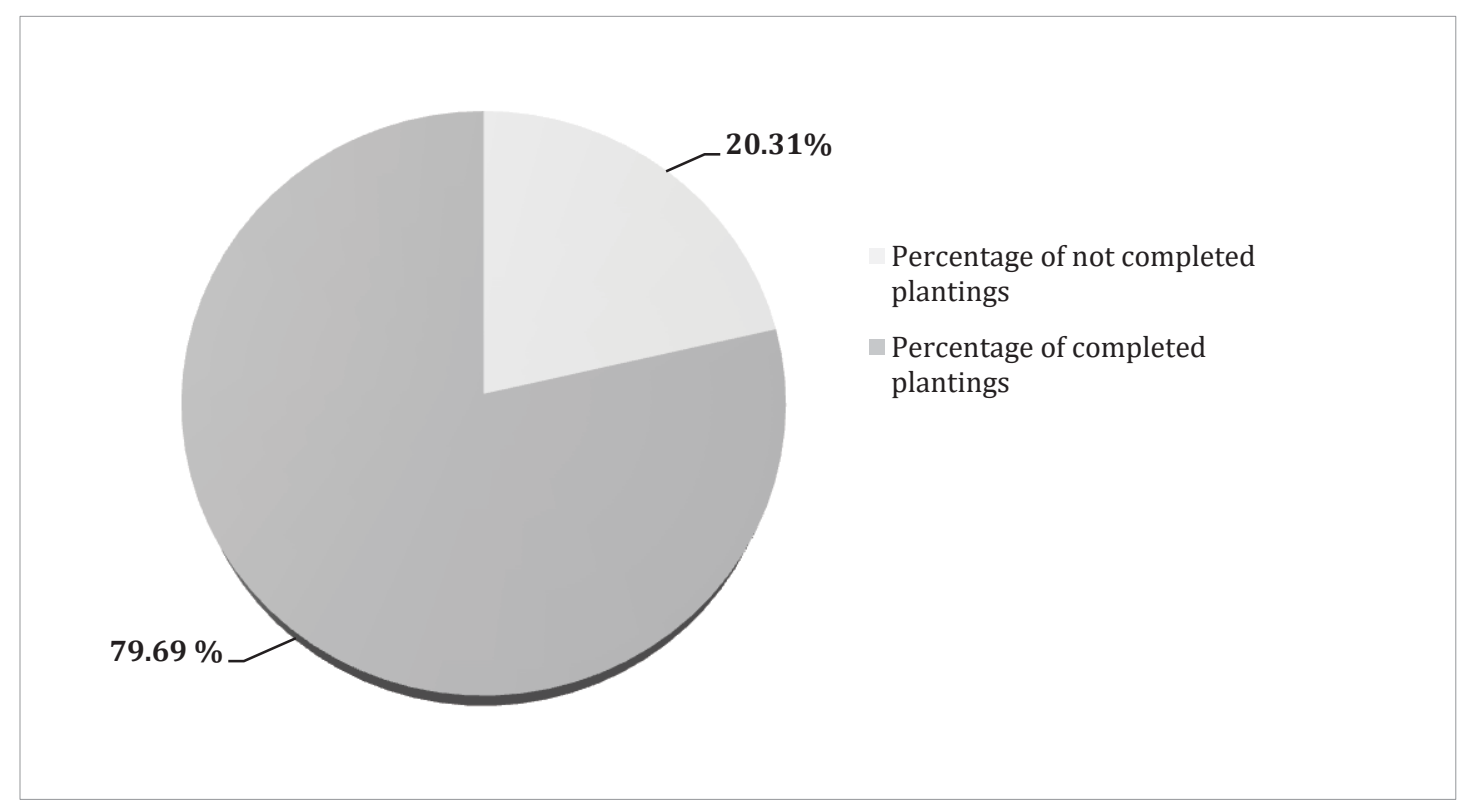

Figure 2. The comparison in percentage of the performed replacement planting 
Table 5. The difference between the replacement value of the removed trees and substitutes (the newly-planted trees)

\begin{tabular}{|l|c|}
\hline \multicolumn{1}{|c|}{ Item } & $\begin{array}{c}\text { Value } \\
\text { (in zlotys) }\end{array}$ \\
\hline The replacement value of the removed trees & $620,234.60$ \\
\hline The replacement value of the new trees & $101,115.45$ \\
\hline Losses (the net value) & $519,119.15$ \\
\hline
\end{tabular}

Table 5 shows the losses in the period of 5 years on the selected area of Praga North. The compensatory value which was reconstituted totals to only $16.30 \%$ in comparison to the incurred losses of $83.70 \%$ (Fig. 3).

In the table 6 the number of trees needed to ensure the complete compensation to the nature (in the terms of the nature conservation act) for the lost value in the result of the removal of trees was calculated. With the aim of reconciling the incurred losses 416 trees with the circumference of 25 centimeters and 378 with the circumference from 26 to 30 centimeters would be needed to be planted.

These numbers illustrate the scale of the loss for the society which occurred due to the elimination of the trees in the period of 5 years. Trees were removed after their death, as dangerous and as a result of collisions with renovations and new investments.

\section{Discussion and conclusion}

The above study approach the problem of removing trees from the city area. On the researched area from 2011 to 2016, there were 64 trees removed and 51 new ones were planted. The amount of the planted substitutes on the selected field is not fully executed in compliance with the basic requirements of the nature conservation act as 13 trees are missing.

Similar situation was observed in Warsaw. According to the Polish Central Statistical Office, in 2008 there were 6,718 trees diminished in Warsaw and 3,930 were planted, what is only $58 \%$. At the same time in the area of Warsaw 3,478 shrubs were removed and 156,415 were planted, i.e. over 40 times more. The increase of the number of shrubs cannot replace the lost tree resources, which are considered on the worldwide scale as crucial elements of the quality of the sustainable urban environment. Moreover, according to administrative decisions issued by the management in Warsaw, in 2009-2014, there were 155,523 trees lost. At that time, only about 8,000 trees were planted on an annual basis (Wojtczuk, 2015). There is the general trend of removing increasing number of trees in urban areas without the implementation of replacement planting (NIK, 2015). For example, in 77 communes examined in the years 1995-1997 there was an increase in the number of trees removed without fees in a collision with infrastructure by more than $50 \%$, and removed as part of the care by almost 100\% (Szczepanowska \& Latos, 2009). Only

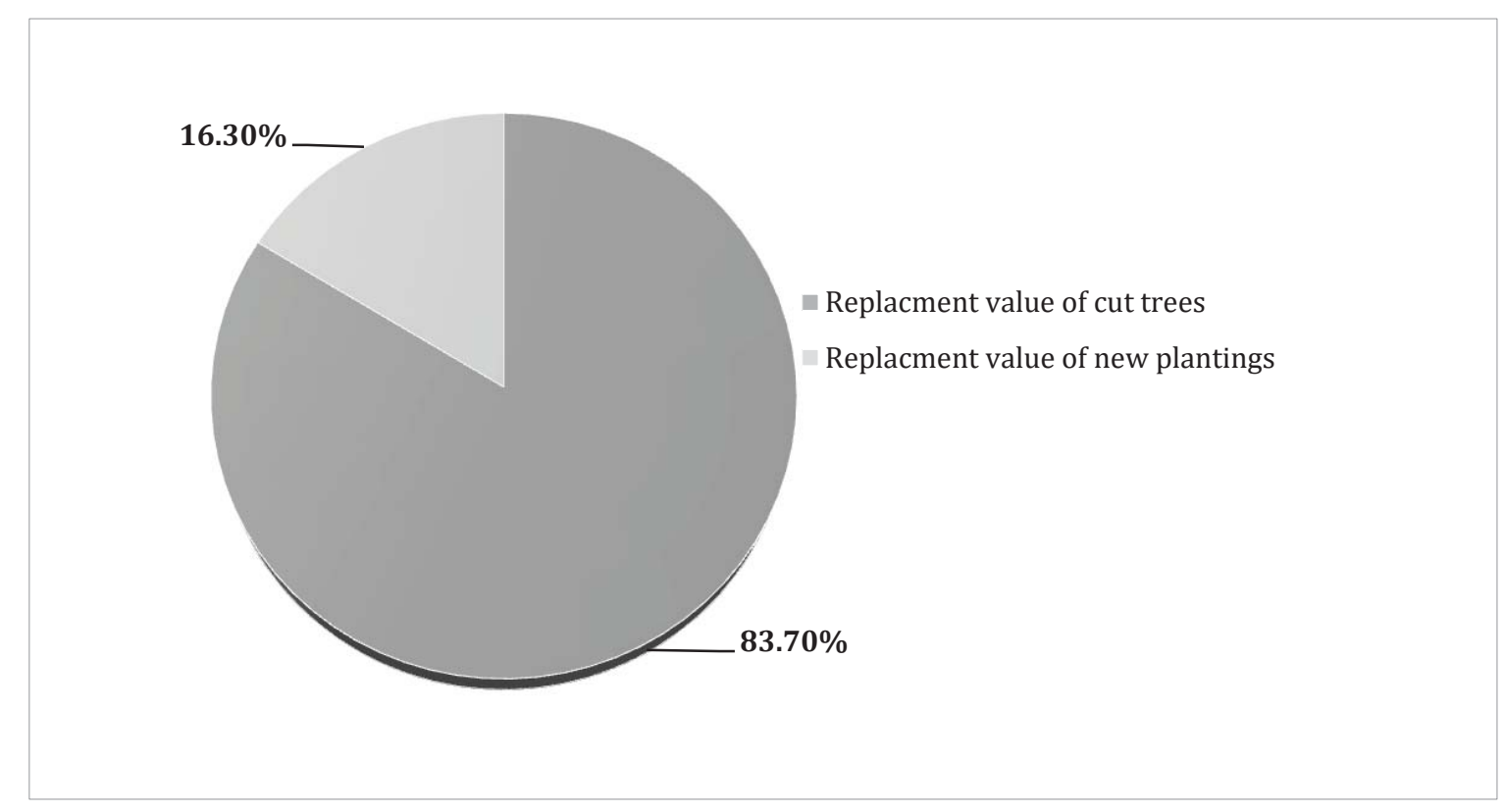

Figure 3. The percentage composition of the removed trees in proportion to the newly-planted ones 
Table 6. The comparison of the replacement value of the trees divided into 4 groups

\begin{tabular}{|c|c|c|c|c|c|}
\hline Item & $\begin{array}{l}\text { The } \\
\text { number of } \\
\text { the trees }\end{array}$ & $\begin{array}{l}\text { Fast-growing } \\
\text { trees (in zlotys) }\end{array}$ & $\begin{array}{l}\text { Moderate- } \\
\text { growing trees (in } \\
\text { zlotys) }\end{array}$ & $\begin{array}{l}\text { Slowly- } \\
\text { growing trees } \\
\text { (in zlotys) }\end{array}$ & Total (in zlotys) \\
\hline Removed trees & 64 & $114,850.40$ & $258,023.96$ & $247,360.24$ & $620,234.60$ \\
\hline Newly plantedtrees & 51 & $20,922.75$ & $41,225.40$ & $38,967.30$ & $101,115.45$ \\
\hline Losses & 13 & $93,927.65$ & $216,798.56$ & $208,392.94$ & $519,119.15$ \\
\hline $\begin{array}{l}\text { SP for the trees with the } \\
\text { circumference up to } \\
25 \text { centimeters }\end{array}$ & & 929.90 & $1,238.00$ & $1,493.00$ & \\
\hline $\begin{array}{l}\text { SP for the trees with the } \\
\text { circumference from } 26 \\
\text { to } 30 \text { centimeters }\end{array}$ & & $1,022.89$ & $1,361.80$ & $1,642.30$ & \\
\hline $\begin{array}{l}\text { The number of the compensatory } \\
\text { planting for the trees with the } \\
\text { circumference up to } \\
25 \text { centimeters }\end{array}$ & & 101 & 175 & 140 & 416 \\
\hline $\begin{array}{l}\text { The number of the compensatory } \\
\text { planting for the trees with the } \\
\text { circumference from } 26 \\
\text { to } 30 \text { centimeters }\end{array}$ & & 92 & 159 & 127 & 378 \\
\hline
\end{tabular}

in 26 analyzed local government units, amounts collected from fees and penalties were allocated for new plantings, and only in 8 communes (which constituted $10 \%$ of the self-government units examined) were allocated for $100 \%$ replacement plantings. In the remaining 18 communes, new plantings were financed in 5 to $50 \%$ of the collected fees. Similar tree studies have been conducted previously (Nixon \& Mims, 1971; Perkins, 1996). This situation happens more often - e.g. many of the species reported in 1994 were removed and not replaced (Creech et al., 1994).

In Poland, the decline in the number of tree is largely related to the low efficiency of replacement plantings. It was being observed in urban areas the high mortality among young trees. It was reported in Warsaw, where the average life span of a tree in the center of the city does not exceed 10 years (Dmuchowski \& Badurek, 2001). Moreover before Foster and Blaine (1978) found that in city centers, young trees are able to survive no more than 7-10 years, what suggest that situation is difficult and still mitigation technics are ineffective.

Most of the tree validation methods consider the location of a tree as an element that influences its value. The nearer a tree is to the city centre, the greater its value, but on another hand in such areas the effects of urban stress on trees are greater, making them more costly to maintain (Contato-Carol et al., 2008). Considering that on the area of research loss of trees may result in difficulties in replanting new plants.

The maintenance and conservation of these spaces, the planning and installation of new ones has become increasingly important for public authorities. Under such circumstances the valuation of trees is required in order to place them on an equal footing with other elements of the urban landscape (Contato-Carol et al., 2008). In our study the difference between the replacement value of the removed trees and the value of the newly-planted trees is significant. The newly-planted trees compensate for the loss of only $18.3 \%$ of the lost value. The number of the compensatory planting (measured on the base of the environmental protection law) constitutes 416 trees. To achieve the full compensation to the nature for the removed 51 trees, there would be 416 young trees needed to be planted with the circumference of up to 25 centimeters. With the aim of the decrease of the number of the trees, there might be 378 trees planted with the circumference of from 26 to 30 centimeters. The problem is that current policy of the planting favours the small decorative trees although the big trees are the most precious ones.

Conducted studies, and previous research as well, suggest that more precise determination of the number of trees to be compensated, requires the adoption of legally sanctioned, comprehensive method. It should refer to a "calcu- 
lator" that enables administrative authorities to calculate the number and quality of new trees that should replace the removed, as is the mentioned case in Germany or the United States (Szczepanowska \& Latos, 2009) as well.

The literature discusses the problem of the valuation method in terms of the value for society (Kulhavy et al., 2014). In Praga North Warsaw district there is the permissible norm of particulate matter concentration exceeded by approximately $40 \%$, breaching the concentration of nitrogen dioxide $\left(\mathrm{NO}_{2}\right)$ (Szczepanowska, 2015). In urban areas, trees are exposed to dying or being removed due to anthropogenic stress. In one of the districts of Warsaw, $20 \%$ of trees have disappeared within the course of 3 years research (Szczepanowska \& Sitarski, 2015). Growth of urban areas due to the influx of people into cities has led to a major deficit in green areas and, by extension, in tree cover (Bradley, 1995). Moreover the amount of removed contaminants is proportional to the surface of the leaves. The very large tree can remove even $60-70$ times more pollutants than a newly planted small tree (Nowak et al., 2002). In order to obtain the balance between the lost benefits of removed and newly-planted trees we have to wait for about 30 to 40 years. With the aim of compensating for the losses we can use the value of the ecosystems.

In the case of lack of space for new planting, the gap in the value between the removed old and the planted young trees can be spent to modify the side conditions for the trees which improves the quality of the soil for the roots grow and in that way prolongs the tree life expectancy.

The principle of sustainable development in the context of urban forest management requires the creation of a comprehensive legal instrument that precisely defines the rules of plantings substitution (Lukasiewicz, 2013; Krynicki \& Suchocka, 2015). Our study shows that tree valuation method could be the efficient factor that supports this process.

\section{References}

Borowski J., Fortuna-Antoszkiewicz B., Łukaszkiewicz J., Rosłon-Szeryńska E., Sitarski M., Suchocka M. \& Wysocki Cz., 2016, Standardy Kształtowania Zieleni Warszawy [Warsaw Greenery Standards]. Katedra Architektury Krajobrazu, SGGW, Warszawa. (http://docplayer.pl/26132041-Standardy-ksztaltowania-zieleniwarszawy.html).

Borowski J. \& Pstrągowska M, 2009, Wyznaczanie współczynników gatunkowych i przyrostowych wykorzystanych do metody wyceny drzew na terenach zurbanizowanych [Determination of tree specific and growth coefficients used in the valuation of trees in urban areas]. Instytut Gospodarki Przestrzennej i Mieszkalnictwa, Warszawa.
Bradley G. A., 1995, Urban forest landscapes: integrating multidisciplinary perspectives. Washington Univ Press, Seattle, WA.

Caballer V., 1989, Modelos para la valoración de plantas ornamentales. Invest Agrar: Econ 4(2): 191-208.

Caballer V., 1999, Valoración de árboles frutales, forestales medioambientales y ornamentales. Ediciones MundiPrensa, Madrid.

Contato-Carol M.L., Ayuga-Téllez E. \& Grande-Ortiz M.A., 2008, A comparative analysis of methods for the valuation of urban trees in Santiago del Estero, Argentina. Spanish Journal of Agricultural Research 6(3): 341-352.

Creech D.L., Singhurst J., Kulhavy D., Seibel G. \& McDonald D., 1994, The woodland vegetation of Stephen F. Austin State University revisited: A CAD/GIS analysis. HortScience abstract 28(5): 482.

Currid P. (ed.), 2000, Guide for Plant Appraisal, Council of Tree \& Landscape Appraisers. International Society of Arboriculture, Champaign, IL, USA.

Dmuchowski W. \& Badurek M., 2001, Zmiany składu chemicznego liści drzew pod wpływem środowiska miejskiego [Changes in chemical composition of leaves of trees under the influence of the urban environment], [in:] B. Gworek, A. Mocka (eds), Obieg Pierwiastków w Przyrodzie, Monografia t. I [Circulation of chemical elements in Nature, Monograph vol. I]. IOŚ, Warszawa: 218-224.

Fabbri M., 1989, Metodi di stima del valore delle piante ornamentali. Acer 2: 15-19.

Felt E.P., 1930, How a tree may be valued. The American City: 102.

Foster R.S. \& Blaine J., 1978, Urban Tree Survival: Trees in the Sidewalk. Jour. Arbor. 4: 14-17.

Hauer R.J., Miller R.W. \& Ouimet D.M.,1994, Street tree decline and construction damage. Journal of Arboriculture 20(2): 94-97.

Helliwell D.R., 2000, Amenity valuation of trees and woodlands (revised ed.). Arboricultural Association, Romsey, Hants, UK.

Kosmala M., Rosłon-Szeryńska E. \& Suchocka M., 2009, Metoda oceny kondycji drzew z uwzględnieniem bezpieczeństwa i uszkodzeń mechanicznych [Method of evaluating the condition of trees with regard to safety and mechanical damage]. Instytut Gospodarki Przestrzennej i Mieszkalnictwa, Warszawa.

Krynicki M. \& Suchocka M., 2015, Nasadzenia kompensacyjne: ekonomiczna, ekologiczna i społeczna wartość drzew [Compensation plantings: economic, ecological and socialvalue of trees]. Fundacja Piaskowy Smok, Katowice. (http://smok.org.pl/2015/05/nasadzeniakompensacyjne-ekonomiczna-ekologiczna-i-spoleczna-wartosc-drzew/). [Assessed: 2112 2017]. 
Kulhavy D.L., Wu D., Unger D.R., Hung I-K, Sun J., 2014a, Comparison of Tree Condition and Value for City Parks and Stephen F. Austin State University in Nacogdoches, Texas, U.S. Arboriculture \& Urban Forestry 40(3): 165-177.

Łukasiewicz A., 2013, Kryteria prawidłowego rozwoju terenów zieleni w aglomeracjach miejskich na przykładzie miasta Poznania [Criteria for the proper development of green spaces in urban areas on the example of the city of Poznań]. Seria Biologia 21: 1-62. Wydawnictwo Naukowe Uniwersytetu im. Adama Mickiewicza, Poznań.

McPherson E.G., 2007, Benefit-based tree valuation. Arboriculture and Urban Forestry 33(1): 1-11.

Miller F.D. \& Neely D., 1993, The effect of trenching on growth and plant health of selected species of shade trees. J. Arboric. 19(4): 226-229.

Morell J.D., 1992, Competition for space in the urban infrastructure. J. Arboric.18(2): 73-75.

NIK, 2015, Ochrona drzew inwestycje. (www.nik.gov.pl). [Assessed: 10-03-2018].

Nixon E.S. \& Mims C.W., 1971, The woodland vegetation of Stephen F. Austin State University. Biology Department Bulletin 1: 30-35.

Nowak D.J., Crane D.E. \& Dwyer J.F., 2002, Compensatory value of urban trees in the United States. Journal of Aboriculture 28(4): 194-199.

Pauleit S., Jones N., Garcia-Martin G., Garcia-Valdecantos J.L., Riviere L.M., Vidal-Beaudet L., Bodson M. \& Randrup T.B., 2002, Tree establishment practice in towns and cities - Results from a European survey. Urban Forestry \& Urban Greening 1: 83-96.

Perkins S.L., 1996, Shade tree analysis of the Stephen F. Austin State University core campus. Master of Science Thesis. Stephen F. Austin State University, Nacogdoches, TX.

Schmied A. \& Pillman W., 2003, Tree protection legislation in European cities. Urban Forestry and Urban Greening 2(2): 115-125.

Simpfendorfer K.J., 1979, Some thoughts on tree valuation. Australian Parks and Recreation, Aug, 45-50.

Stone O., 2000, Tree Valuation, Readers Forum. Arborist News 9 (3): 55.

Suchocka M. \& Krynicki M., 2016, Analiza możliwości i zakresu stosowania nasadzeń zastępczych za usuwane drzewa w kontekście nowelizacji ustawy o ochronie przyrody [Analysis of the opportunities and the scope of implementing the replacement planting in place of removed trees in the context of revised nature conservation act]. Ekonomia i Środowisko 2/57: 259-273.

Szczepanowska H.B., Sitarski M., Suchocka M., Kosmala M., Rosłon-Szerzyńska E., Borowski J., Olizar J., Pstrągowska M., Dmuchowski W., Latos A. \& BiałeckaKornatowska B., 2009, Metoda wyceny wartości drzew na terenach zurbanizowanych dla warunków polskich [The method of determining the value of trees for Polish conditions]. Instytut Gospodarki Przestrzennej i Mieszkalnictwa, Warszawa.

Szczepanowska H.B., 2015, Drzewa w mieście-zielony kapitał wartości i usług ekosystemowych [Trees in the city-greencapital of values and ecosystem services]. Człowiek i Środowisko 39 (2): 5-28.

Szczepanowska H.B. \& Latos A., 2009, Synteza badań i założenia merytoryczne metody wyceny wartości drzew dla warunków polskich [Synthesis of research and substantive assumptions of the method for the valuation of trees for Polish conditions]. Instytut Gospodarki Przestrzennej i Mieszkalnictwa, Warszawa.

Szczepanowska H.B. \& Sitarski M., 2015, Drzewa - zielony kapitał miast [Trees - green capital of the cities]. Instytut Gospodarki Przestrzennej i Mieszkalnictwa, Warszawa.

Ustawa z dnia 16 kwietnia 2004 r. o ochronie przyrody, Dz.U. 2015 poz. 1651, 2015. Kancelaria Prezesa Rady Ministrów [Nature Conservation Act of 16 April 2004, Journal of Laws 2015 item 1651, 2015. Chancellery of the Prime Minister], Warszawa.

Ustawa z dnia 27 kwietnia 2001 r. Prawo ochrony środowiska, Dz.U. 2001 Nr 62 poz. 627, 2001. Kancelaria Prezesa Rady Ministrów [Environmental Protection Act of 27 April 2001, Journal of Laws 2001 No. 62 item 627, 2001. Chancellery of the Prime Minister], Warszawa.

Wojtczuk M., 2015, Obezwładniające: w Warszawie w 6 lat wycięto aż 150 tys. drzew [Overwhelming sense of helplessness: as many as 150,000 trees were cut down within 6 years]. „Gazeta Wyborcza”. (www. m.warszawa.gazeta.pl). [Assessed: 20-06-2015].

Ziemiańska M. \& Suchocka M., 2013, Planowanie i zasady ochrony drzew w procesie inwestycyjnym [Planning and principles of tree protection in the investment process], [in:] T. Bergier, J. Kronenberg, P. Lisicki (eds), Zrównoważony rozwój, zastosowania. Fundacja Sendzimira, Łódź: 10-25. 